\title{
Carcass and Meat Quality in Goat
}

\author{
Ana Guerrero, María del Mar Campo, \\ José Luis Olleta and Carlos Sañudo \\ Additional information is available at the end of the chapter
}

http://dx.doi.org/10.5772/intechopen.72095

\begin{abstract}
Goat is a worldwide spread species with different specialities and aptitudes, among the meat production. Its consumption varies widely depending on the region of the world considered. However, a common factor is the presence of few studies in comparison with ovine, especially those that characterize the quality of its products (related to carcass and meat). Generation, availability, and diffusion of characteristics of the species and its production, generated from scientific studies, could help breeders and society on their education and raising global awareness of its importance, conservation, and productive possibilities. Goat has its own specific characteristics related to quality with a presumed good acceptability of its products by consumers. On the current chapter, the effects of the main factors that modify carcass and meat quality in goat are compiled. Both, intrinsic factors (breed or breed type, age, weight at slaughter or gender) and some extrinsic factors (as production system, type of suckling, and aging) are discussed.
\end{abstract}

Keywords: acceptability, instrumental analyses, kid, proximate composition, sensory

\section{Introduction}

Goat is the most widespread livestock species, as [1] reported and listed. There is an important visible genetic variation on goat species, with approximately 570 different breeds, with their own morphological characteristics, productive performances, and adaptation to specific climate and environment. Breeds are classified in 5 specialities: meat, milk, prolificacy, fiber (pashmina-cashmere and mohair), and skin. Currently, there are more than 1 billion heads around the world [2], with 57.4\% of the census located in Asia, 37.0\% in Africa, and 3.5\% in America, representing Europe $1.6 \%$ and Oceania $0.4 \%$. Over the last 50 years, as [3] compiled, goat population has multiplied by 2.4 times while other livestock species have maintained it or reduced. Nevertheless, goats in most countries are kept in small herds, not always very 
profitable and in various aspects dependent on different monetary or political supports from governments or local entities, as it was concluded in the 2014 European Regional Conference [4]. Goat has demonstrated to be a really important livestock in different parts of the world, mainly due to its versatility and high adaptation's capacity to different production systems from the high intensification, in the most developed countries on dairy herds, to the hard conditions of arid areas. On the other hand, some studies have shown that a correct management of goats on grasslands can also help to increase plant biomass and biodiversity [3], having also a social function by fixing people to the territory, avoiding more movements to big nucleus-cities, and consequently depopulating the rural areas.

To support goat production is necessary the generation, availability and diffusion to the people, of new and diverse information related to characteristics of the species, possibilities of production, product quality and its benefits for the humanity's future [4]. As already [1] pointed in the last decade, the possible benefits from science advances on several fields, considering goat, are not yet so extent as on other livestock species, although that scientific generated information could help breeders and society on their education and raising global awareness of the species. Because the knowledge generated can be applied on everyday management, building a more sustainable and prosperous future on goat. With this aim of spread knowledge and application of the science, in this chapter, factors that affect carcass and meat quality will be analyzed, mainly focusing on the expertise and experience obtained from experimental studies and results developed by the authors.

\section{Material and methods}

In general a standardization of methodologies in any field of research would be necessary. This would allow the creation of universal and homogenous databases, letting the comparison of studies and their diverse variables in a global way around the world. This idea is more than a necessity in the twenty-first century.

Related to carcass quality in small ruminants, it is fundamental to compile some basic information about animals, as age and weight, that let an official classification according to the different categories existent depending of each State legislations. Afterward, an external classification according to morphology and fatness is necessary, using the official European Systems based on photographic models [5, 6]. Also morphological measurements, as those suggested by [7-9], help to compare carcass characteristics, in an objective way, including compactness indexes of the studied animals. In the same way, a standard protocol for cutting and dissect representative parts of the carcass (shoulder or leg) could be important, as those reported by $[8,10]$, to obtain information about tissular composition and the real value of commercial cuts.

Evaluation of meat quality can be defined by different attributes or variables. Firstly, monitoring $\mathrm{pH}$ with a commercial $\mathrm{pH}$ meters is necessary to verify the absence of alterations in this parameter, a fact that would modify other meat quality variables. An objective definition of color using the CIEL $\mathrm{a}^{*} \mathrm{~b}^{*}$ system with diverse types of spectrocolorimetres let define color in some basis variables as luminosity $\left(\mathrm{L}^{*}\right)$, yellowness $\left(\mathrm{b}^{*}\right)$, redness $\left(\mathrm{a}^{*}\right)$, tone $\left(\mathrm{H}^{\circ}\right)$ or chrome $\left(\mathrm{C}^{*}\right)$. The standardization of measuring conditions, as instance blooming, should be indicated. 
Texture analyses are assessed by texturometers which have different blades that let obtain mainly values related to shear force or resistance to compression of meat samples (raw or cooked). Some standard protocols to determine texture have been proposed by Honikel and Lepetit and Culioli [11, 12] and summarized in [13]. Proximate composition of meat can be defined by the quantification of its different components such as moisture, ash, protein, or fat evaluated according to International Organization for Standardization Protocols (ISO). For the fatty acid analysis, intramuscular fat can be extracted by various protocols as those suggested by [14] and after the methyl esterification samples are analyzed by gas chromatography. Related to sensorial analyses, a trained panel let obtain objective scores of the sensorial attributes of meat [15] and the use of different kinds of consumer hedonic test show the acceptability of consumers related to the product [16]. Detailed information about different methodologies cited in this section and along the chapter can be consulted in [17-19].

\section{State of the art: goat meat production and some general concepts about product quality}

The billon of goat census by FAO on 2014 [2], produced 5,524,075 annual tonnes of meat. According to the world distribution of goat, the main meat production occurs in Asia $(71.9 \%)$, followed by Africa (23.5\%), America (2.2\%), and Europe (1.9\%), being the production in Oceania only $0.5 \%$ of the total meat goat production. Classifying those data by countries, the top five producers currently are: China (2,098,100 t), India (505,064 t), Pakistan (309,000 t), Nigeria $(244,575 \mathrm{t})$, and Bangladesh (208,613 t). In Europe, the situation has not changed too much in the last years [3], with a low goat meat production compared to the previously described top five, being Greece the country with the largest meat production (23,893 t), followed by Eastern European countries such as Russian Federation (17,515 t), Albania (14,850 t), and Romania (9126 t); France and Spain also presented a significant production with $12,077 \mathrm{t}$ and $8010 \mathrm{t}$, respectively.

The differences between the commented countries or world regions, can reside in the own use and habits of consumption of goat meat. Especially for consumers in developing countries [20], goat food products represent an important nutrient source, being this species an important part of the habitual diet of the population, as well as an important resource for income (until more than $70 \%$ of the total on small holder farms [1]). However, for Western consumers, goat food products (particularly dairy products) are considered luxurious, and goat meat consumption has a low frequency rate, being mainly associated to punctual-festive events, specific regions, or associated to label quality brands as a high-quality difference product.

The concept of quality is complex and dependent on the aspect that it is considered. Usually, quality is defined as "All those attributes for what consumers are willing to pay more," or an extra in the base prize in order to have some specific attributes guaranteed. Quality can be associated to different aspects as nutritional attributes (low fat content or healthy fat profile), production system (sustainable, organic or welfare friendly, for instance) or particular sensorial attributes (optimal odor, texture or flavor and, at the end, some extra hedonic satisfaction). Many of these aspects could be related with certain quality labels that support or guarantee the extra paid quality. 
To determine quality in relation to meat, we should focus on a specific market [21]. Meat quality needs studies in depth, being a complex topic which presents a lot of questions and aspects to be dealt both, in general (animalism, sustainability, and human health) and with the goat meat in particular (habits, prices, problems of availability and a lack of culture about its specificities and own characteristics). Some of these points (all related with the culture, information, and adaptation to some tendencies of the new markets) could be satisfied with information and adequate labels. The label is the industry and producers' way of communicating directly with the consumer. It should be attractive with a good design, and if possible interactive, providing information on the product's origin and background, its nutritive and sensory qualities and veracity between the written and the reality [21].

At the end, increasing demand and improving marketing for meat should entail increased production, which must be worthwhile for producers, sustainable for the planet, economically profitable for the production chain, of healthy quality, as well as affordable for consumers [21].

\section{Main factors that affect carcass and meat quality in goat}

There are several factors that affect the final quality of the product related to carcass and meat. Those, as it is compiled in Figure 1, can be classified as intrinsic or extrinsic [22].

Due to the high quantity and variability of factors, only some of them will be discussed in the current chapter, those which usually produce more variations. Thus, as intrinsic factors,

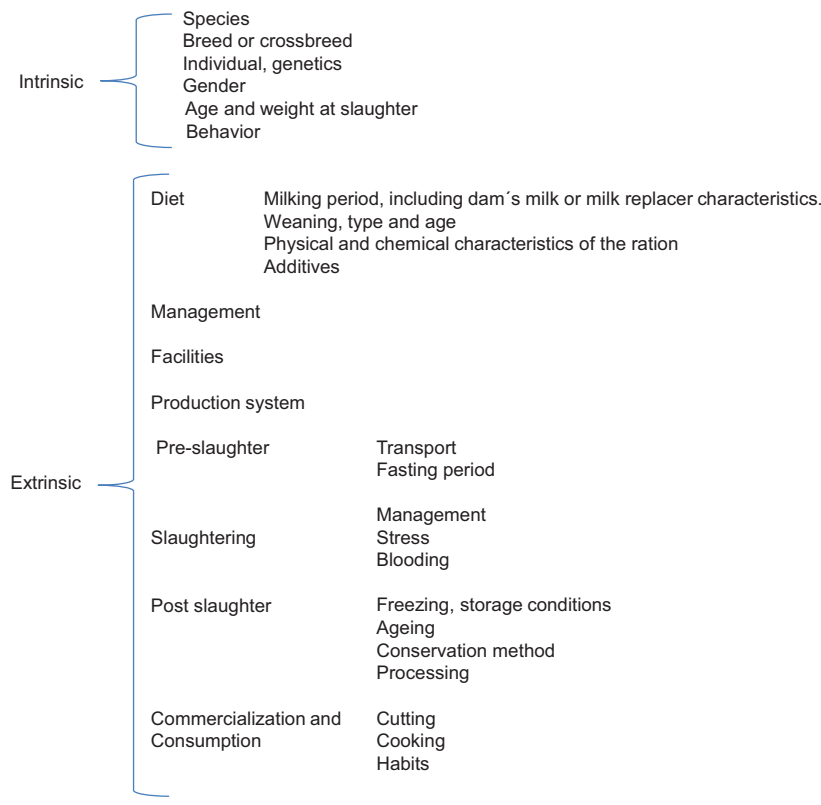

Figure 1. Main factors that modified carcass and meat quality in goat. Source: Adapted from Ref. [22]. 
we will analyze breed or breed type (dairy vs. meat aptitude, rustics vs. specialized breeds), age or weight at slaughter, and gender and, as extrinsic factors, we will analyze the effects of production system, type of suckling (dam's milk vs. milk replacer), and post-slaughter aging.

\section{Carcass quality}

Carcass quality parameters are mainly divided on those that affect morphology, as conformation and morphological measurements, and those related to composition as commercial cuts, fatness score or tissular or chemical composition. Tissular composition is usually obtained as percentage of tissue components from the complete carcass or from specific commercial cuts after a standard cutting and dissection $[10,23]$.

Carcass traits, such as the conformation as well as fat distribution within the carcass, have a great importance in meat production, because of their economical implications. The proportion of high value cuts is an indication of its overall value, having, some carcasses attributes concerned with the quantity of saleable meat, significant implications on the technological properties of the meat, i.e., the morphology of some specific muscles and cuts [24].

\subsection{Weight, conformation and morphological measurements}

Average carcass weight differs depending on the continent or country considered, being $12 \mathrm{~kg}$ a world average, and $10 \mathrm{~kg}$ for Europe or Spain [1]. Carcass performance on suckling kids of $6-10 \mathrm{~kg}$ of life weight can present values between 60 and 65\%, because in young animals, only skin and white offals are excluded. In old animals, head and red offals (liver, hearth, spleen, lungs, etc.) are also excluded, presenting a carcass performance of around 50\%.

Conformation is used to describe carcass morphology and the visual impression that the different categories produce on the observer [25]. It can be assessed in a comparative way with photographic models, or using measurements based on different anatomical points. For goat species, it does not exist an official classification system of carcass quality, as happens in other ruminants (European System SEUROP for conformation), although some authors have done some proposals [23, 25, 26]. In Spain goat, carcass is classified by animal age as: suckling kid (younger than 1.5 months), young goat (between 1.5 and 6 months of age), and adults (older than 6 months).

Some studies have showed that carcass quality can differ significantly among breeds, but differences mainly depend on the criteria used in the comparisons (same weight, same age, or same proportion of mature weight). The results will be different depending on the comparative criteria employed.

For example, at commercial slaughter weights, unweaned kids from dairy or meat breeds reared on their dam's milk, following the local husbandry practices that differed significantly in conformation notes and morphology variables [24]. Average carcass weights ranged from $4.38 \mathrm{~kg}$ (dairy breed) to $6.56 \mathrm{~kg}$ in some meat breeds. Also, products from dairy breeds presented lower conformation (1.70 in a 15 points scale: from 1 poor: poorly muscled carcasses of inferior shape, to 15: excellent, carcasses of outstanding shape) than those from meat breeds. 
Related to kid morphological measurements, when data from Ref. [24] were covariated by the carcass weight, smaller differences were appreciated between dairy and meat purpose animals. Thus, some meat breeds presented the longest pelvic limb, but dairy or meat breeds did not statistically differ either on carcass external length, buttock width or chest depth, showing small differences in morphology, independently of their main aptitude. This applies to the most local breeds, which are not meat specialized as Boer, at young slaughter ages.

According to data compiled by [27], which show more than 60 different commercial types from several locations around the world, age, and live weights, differences between breeds on carcass yield are associated to the final size of the breed, degree of fatness, and aptitude. The lowest performances have been reported in animals of 120-180 days of age, from Chilean Creole breed, with a $45.1 \%$ carcass yield [28], and the highest at young Gigertana kids of 25 days of aging with a $70.6 \%$ carcass yield [29]. On the other hand, from a commercial point of view, an increment on slaughter weight from 4 to $6 \mathrm{~kg}$ may not improve cold carcass yield in Serrana meat breed [27].

Age and, consequently, maturity are the most important factors that modify carcass characteristics [30]. Final carcass weight increased on the meat purpose breed Serrana in kids from 10 to $40 \%$ of the final adult weight (FAW); however, the performance of 20 and 30\% were lower (46.2-46.6\% respectively) than those obtained at $10 \%(51.4 \%)$ or $40 \%(47.9 \%)$ of the FAW. On the same study [30], the gender had a significant effect on live and carcass cold weights; however, no differences were reported on carcass yield. In Ref. [31], it was found that males presented the greatest weights and average daily gains related to females, especially when came from 3 to 5 years old animals, as well as in single born animals and in autumn.

Different breeds produce differences in morphological measurements ranging thoracic depth from $15.7 \mathrm{~cm}$ to $31.4 \mathrm{~cm}$ or buttock perimeter from 42.6 to $53.0 \mathrm{~cm}$, being not homogenous the effect of the gender on those variables [27]. Also, results [27] showed that an increment in slaughter weight also presents an increment in morphological measurements of the carcass, which improve carcass compactness index (carcass weight/length carcass), although without effect on leg compactness.

\subsection{Carcass composition and fatness}

For fatness score, a classification has been developed with a 5 points scale from 1 (very lean or very low fat cover) to 5 (when the carcass is completely covered) [25].

Breed has been described as an important effect in composition and fatness. Related to the fatness score described in [25], a Spanish meat breed such as Blanca Celtibérica presents the highest fatness score [24], because it is normally consumed at heavy slaughter weights (6.56 kg cold carcass weight-CCW). However, within suckling animals (the most consumed in Spain), some dairy breeds (Murciano-Granadina) show higher scores (highest fatness) than local meat purpose breeds, even when those parameters are covariated by CCW, showing their highest precociousness. 
According to Ref. [10], carcass in small ruminants can be divided into five main regions corresponding to different commercial cuts: leg, ribs, flank, shoulder, and neck. Some results obtained from several studies with cold carcass weights from 3.2 to $16.0 \mathrm{~kg}$ are compiled in Table 1, being the variability mainly dependent on the studied breed and slaughter weight.

According to allometric coefficients [32], when the weight of an animal increases, there is a decrement in the percentage of bone and an increment in the percentage of fat, being the muscle kept almost constant. Early developed cuts are the leg and shoulder, being ribs and flank the late developed cuts [27].

Tissue composition highly affects commercial quality of the carcass. As happens in other species, as ovine, consumers pay the same price for fat, muscle, and bone, all inclusive in the commercial cuts. Due to this, fat composition is an important factor to consider. It has been reported a great variation on the composition between goat breeds [10, 24]: muscle between 69 and 50\%, 34-11.8\% for bone (a high rate correspondent to young animals), and a percentage of fat between 23.7 and 5\%, that could be considered, in general, as low, but it depends of the age, breed and, obviously, fatness score. A dairy breed such as Murciano-Granadina presents the lowest subcutaneous fat percentage, although not different from the local meat purpose breeds, reflecting the tendency for dairy breeds to store more visceral than carcass fat. This visceral deposit has been described as precocious, and it might develop quicker because of the high nutritional level of dairy kids that results from their high dam's dairy production potential [24].

In Ref. [33], it has been described that natural suckling gives higher fatness score and weight of renal fat, compared to kids fed with milk replacer. These results suggest a better assimilation of the natural than artificial milk, although it could also be associated with differences in composition between milks.

On meat aptitude goats, Ref. [27] found a stronger effect of age or final body weight than gender. With the increase of body weight (carcass weight from 4 to $8 \mathrm{~kg}$ ), fat percentage increased $4 \%$ and bone percentage decreased the same amount, having females almost $2 \%$ points more of fat and less of bone. No differences in muscle percentage were reported. Consequently, relation muscle/bone was better for female than male kids.

\begin{tabular}{ll}
\hline Cut & Variability (\%) \\
\hline Leg & $33.6-26.4$ \\
Rib & $32.5-21.7$ \\
Flank & $13.6-9.5$ \\
Shoulder & $25.7-17.9$ \\
Neck & $12.6-7.4$ \\
\hline
\end{tabular}

Source: Adapted from Ref. [27].

Table 1. Percentage of different commercial cuts on goat carcasses. 
In general, it could be said that goat carcasses are longilinear and, consequently, they have a poor conformation. Also, they have high muscle and bone percentages and low content of fat, especially subcutaneous fat.

\section{Meat quality}

\section{1. $\mathrm{pH}$}

$\mathrm{pH}$ can be considered one of the most important and basic factors that can affect meat quality. Nevertheless, goat is a species in which alterations with low pH (PSE) or high pH (DFD) are not usual.

Several studies have reported differences in $\mathrm{pH}$ between breeds but probably more associated to differences in the management previous to the slaughter than to the own breed. Thus, Colomer-Rocher et al. and Ripoll et al. [24,34] at same weight and management reported statistical differences between breeds. However, these differences can be considered insignificant (5.76-5.80). In Ref. [13], slight differences that are dependent on carcass weight, where $\mathrm{pH}$ was lower on heavier carcasses $(8 \mathrm{~kg}-5.8 \mathrm{pH})$ respect to less mature animals $(4 \mathrm{~kg}-5.9$ $\mathrm{pH})$, were reported. Gender usually does not modifies $\mathrm{pH}[27,35]$.

\subsection{Color}

Color is an important attribute that affects consumer purchase and willingness to buy. Preferences for a specific color (paler or darker) depend on the type of consumer considered (usually conditioned by the nationality, cultural background and experience or consumptions habits [36]).

Some differences have been reported among breeds [37], due to the different aptitudes of the breeds or crossbreds compared: fiber, dairy, and meat. The highest luminosity $\left(\mathrm{L}^{*}\right)$ have been reported on crossbred meat $x$ dairy genotype (Boer $\times$ Saanen) and the lowest redness $\left(\mathrm{a}^{*}\right)$ and yellowness $\left(b^{*}\right)$ for meat and wild goat crossbred genotype (Boer $\times$ Feral).

In Ref. [34], differences in $L^{*}$ between breeds on light weight animals were not reported. Obtained values and differences can be considered low and explained by the milk-based diet of young animals, since milk is not rich in iron which would darken the meat. However, [38] found differences between kids from dairy or meat aptitude, presenting dairy animals breed (Murciano Granadina) significant higher $\mathrm{L}^{*}$ and $\mathrm{H}^{\circ}$ (almost 10 points) than those from meat aptitude (Bermeya), without differences on $b^{*}$ between breeds.

In Table 2, some color variables of different studies are compiled, showing the variability on this parameter depending on the factors considered.

Related to age and weight, the results from Ref. [27] showed that color of Longissimus was statistically modified. Increasing CCW $(4-8 \mathrm{~kg})$ produces a progressive reduction of luminosity ( $\left.L^{*}: 49.0-43.6\right)$, and an increment of redness ( $\left.a^{*}: 9.4-13.8\right)$ without variation of 


\begin{tabular}{llllllll}
\hline $\mathbf{L}^{*}$ & $\mathbf{a}^{*}$ & $\mathbf{b}^{*}$ & $\mathbf{H}^{\circ}$ & $\mathbf{C}^{*}$ & Breed & Weight $\mathbf{( k g )}$ & Reference \\
\hline $55.1-49.1$ & $13.4-10.6$ & $5.8-5.3$ & $28.7-23.4$ & $14.6-12.1$ & $\begin{array}{l}\text { Spanish kids (meat and } \\
\text { dairy apt) }\end{array}$ & $4.3-6.5 \mathrm{CCW}$ & {$[24]$} \\
$55.2-52.9$ & $11.7-9.3$ & $20.9-14.5$ & $62.1-54.4$ & $23.6-18.0$ & 5 Spanish kids meat apt. & $7.4-8.0 \mathrm{SW}$ & {$[34]$} \\
$53.4-48.3$ & $13.8-9.2$ & $19.3-12.9$ & $59.9-44.3$ & $22.0-17.7$ & 5 Spanish kids meat apt. & $10.9-12.3 \mathrm{SW}$ & {$[34]$} \\
$49.0-43.6$ & $13.8-9.4$ & $10.0-9.3$ & $46.4-35.1$ & $16.8-13.6$ & Portuguese kid meat apt. & $4-8 \mathrm{CCW}$ & {$[27]$} \\
$43.6-37.7$ & $12.4-10.3$ & $8.1-6.7$ & $35.4-31.2$ & $14.5-12.4$ & $\begin{array}{l}\text { 6 crossbreeds different } \\
\text { apt. }\end{array}$ & $\begin{array}{l}11.8-10.9 \\
\text { CCW }\end{array}$ & {$[37]$} \\
\hline
\end{tabular}

$\mathrm{CCW}$, cold carcass weight; SW, slaughter live weight.

Table 2. Color attributes of goat's meat from different studies.

yellowness $\left(b^{*}\right)$ with values between 9.3 and 10.0. Differences in color are probably associated with the increment of myoglobin because the concentration of this pigment has been demonstrated that increases with the animal age, increasing color intensity [27, 39].

Similar results were reported in [34], where heavy weight kids (11 kg live weight) presented almost 3-4 points lower luminosity than light weight kids (7.6 $\mathrm{kg} \mathrm{LW})$; however, redness was not modified and $b^{*}$ decreased only in some meat breeds, without modification in other meat purpose breeds. Guerrero et al. [38] on meat breed Bermeya slaughtered at $7 \mathrm{~kg}$ or $10.5 \mathrm{~kg}$ CCW, only reported differences in redness and Chrome variables which increase with the slaughter weight. Then, in general terms, $\mathrm{L}^{*}, \mathrm{~b}^{*}$, and $\mathrm{H}^{\circ}$ diminished, and $\mathrm{C}^{*}$ and $\mathrm{a}^{*}$ increased their values with the increasing slaughter weight.

As happened in $\mathrm{pH}$, no differences in color have been associated to gender $[27,40]$.

Related to productive system and age, Dhanda et al. [37] reported differences between meat purpose goats, from suckling kids and low slaughter weights (Capretto 6-12 kg) to older goats with carcass weight of 16-22 kg. Total pigment concentration in the Longissimus muscle was significantly higher in Chevon compared to Capretto carcasses, and a modification in color intensity is expected. However, only differences in $b^{*}$ were reported in the cited study, explained as a difference of slaughter age (5 months).

\subsection{Texture}

Aging is the most important factor that modifies meat texture and consequently eating quality, consumer acceptability, and satisfaction. The metabolic-biochemical reactions that happen after rigor mortis let a progressive tenderisation of the meat [41]. Tenderness can be evaluated instrumentally by texturometers or by sensory methodologies. In this section, only instrumental characteristics will be assessed. As happened in lamb, the period comprised from 3 to 8 days of aging seems to be enough to reach a desirable tenderness without damaging sensory perception [16, 22]. It is important to consider this factor (aging) and try to isolate it (using the same meat aging conditions on the comparisons) to understand the effect of other factors on texture variables. 
Usually, as happens in other ruminant species, breed modifies texture parameters, especially when different aptitudes are compared. This happened in Ref. [37], where after $24 \mathrm{~h}$ of aging, a crossbred with a meat breed (Boer $\times$ Feral) presented significant lower shear force values $\left(3.7 \mathrm{~kg} / \mathrm{cm}^{2}\right)$ than a dairy crossbred (Saanen $\times$ Feral, $\left.4.6 \mathrm{~kg} / \mathrm{cm}^{2}\right)$.

In Ref. [34], it was reported that the three meat compression variables studied (C20\% - related to myofibril component, $\mathrm{C} 80 \%$ - related to connective component-collagen and the maximum compression ratio $\mathrm{C} 100 \%$ - the force necessary for the total compression [12]), were affected by both breed and slaughter weight factors. Differences of almost $5 \mathrm{~N} / \mathrm{cm}^{2}$ were reported between different meat breeds at $20 \%$ of compression, $16 \mathrm{~N} / \mathrm{cm}^{2}$ at $80 \%$, and $23 \mathrm{~N} / \mathrm{cm}^{2}$ at $100 \%$, being the maximum values of $14.96,79.74$, and $101.70 \mathrm{~N} / \mathrm{cm}^{2}$ for $\mathrm{C} 20, \mathrm{C} 80$, and $\mathrm{C} 100 \%$, respectively.

In the cited study [34], aging of samples was 3 days. The higher myofibrillar toughness of light kids could be explained by a lower activity of muscle proteolytic systems, as well as a lower rate of post mortem tenderisation, or higher myofibrillar density due to the short age of light kids. As a general rule, by increasing the aging time, tenderness will increase [42]. Tenderizing is more intense in older animals due to the higher action of the proteases.

Results from Ref. [38] reported that breed was only a significant factor of variation at short aging periods (2 days) on C20\% variable, where meat from a dairy breed was tougher than those from meat breed kids at both slaughter weights (light or heavy carcasses). However, at 4 days of aging, those differences between breeds disappeared, being most significant the effect of aging tenderizing than the effect of the breed purpose.

According to Ref. [40], gender did not affect texture parameters also after 3 days of aging, in which medium values are between 8.3 and $8.4 \mathrm{~kg} / \mathrm{cm}^{2}$ on shear force.

\subsection{Proximate composition and fatty acid profile}

Goat meat can be considered as red meat, as those from other small ruminant species, according to its proximate composition. As some authors [20] have pointed before, meat from goat has a high nutritional value, contributing to an enjoyable and healthy human diet.

Goat meat compared to the other ruminant meats is characterized by a higher water content, lower energy contribution as well as lower fat content, with a similar proportion of minerals (Table 3). Values are dependent on the source consulted (USDA; BEDCA). The type of animal and the piece used in the determination of proximate composition explain the variations reflected in Table 3.

In Ref. [34] were not found differences between breeds on chemical composition neither on light or heavy kids, being comprised between 78.01 and $76.97 \%$ for moisture, 24.11 and $19.52 \%$ for crude protein, 1.11 and $1.03 \%$ for ash and 2.05 and $1.09 \%$ for fat. However, the results from Ref. [38] showed that differences between aptitudes exist specially in fat percentage, where commercial dairy kids presented higher percentage (7.49\% vs. $1.9-2.8 \%)$ than kids from meat aptitude even at lower carcass weight. 


\begin{tabular}{lllll}
\hline & Goat [43] & Lamb [43] & Kid [44] & Lamb [44] \\
\hline Water, g & 75.84 & 71.40 & 64.50 & 64.10 \\
Energy, kcal & 109 & 142 & 225 & 242 \\
Protein, g & 20.60 & 19.98 & 17.11 & 15.60 \\
Total lipids (fat), g & 2.31 & 6.88 & 17.49 & 20.10 \\
Minerals & & & & 9.00 \\
Calcium, mg & 13.00 & 18.00 & 9.56 & 2.60 \\
Iron, mg & 2.83 & 1.52 & 0.57 & 16.00 \\
Magnesium, mg & - & 23.00 & 15.82 & 170.00 \\
Phosphorus, mg & 180.00 & 189.00 & 156.77 & 320.00 \\
Potassium, mg & 385.00 & 327.00 & 248.93 & 75.00 \\
Sodium, mg & 82.00 & 77.00 & 64.06 & 2.20 \\
Zinc, mg & 4.00 & 2.69 & 2.24 & \\
\hline
\end{tabular}

Source: [43]: goat raw (Ref. 17168); lamb, New Zealand, imported, loin chop, separable lean only, raw (Ref. 17078). [44]: milk kid ribs-Murciano-Granadina (raw); lamb ribs (raw).

Table 3. Basic composition characteristics of different ruminant species. Values per $100 \mathrm{~g}$ of an edible portion.

Slaughter weight also did not affect proximate composition [34], only fat percentage for the meat breed Pirenaica, which proportion decrease with the age of the animal from 2.05 to $1.37 \%$. Those results from Ref. [34] agree with others [29, 45] were slaughter weight did not affect the chemical composition of the loin in young animals. Usually ash and fat content is low on kid meat, and main differences between breeds on chemical composition are associated to intramuscular fat. However, [38] reported small differences between slaughter weights on other chemical components, where animals from heavy carcass presented lower moisture percentage ( $75.7 \%$ vs. $77.8 \%)$ and higher protein content (18.8\% vs. $17.1 \%)$ than light kids (which had $3.5 \mathrm{~kg}$ less of carcass weight).

Gender was unaffected by dry matter and fat percentage in kids with CCW of 4.5-5.0 kg; dry matter was reported as $24.1-23.8 \%$ in females and males, respectively, and the fat content $1.7-1.4 \%$ [40], similar to other breeds (meat aptitude).

Fatty acid composition is an important attribute to be considered by their implication in human health. Also fat composition affects organic attributes, especially those related to flavor, and consequences of lipid oxidation (rancidity).

In Ref. [46], the fatty acid profile of three different depots (intramuscular, subcutaneous, and kidney knob fat) from seven Spanish breeds from meat and dairy aptitude, in kids slaughtered at $7 \mathrm{~kg}$ live weight was analyzed. There were differences between breeds on all depots studied, and the differences being more evident between aptitudes (meat and dairy). A dairy breed (Malagueña) showed higher percentage of monounsaturated (MUFA) and conjugated 
linoleic (CLA) fatty acids than meat breeds. The highest percentages of saturated fatty acids appeared in meat breeds. Also, Horcada et al. [46] reported that it is possible to separate breeds and production system groups by discriminant analyses based on the differences between CLA and percentage of polyunsaturated (PUFA) fatty acids $n-6$ and $n-3$ and its ratio, for both intramuscular and subcutaneous fats. Also, dairy breeds are clearly separate from the other breeds by the composition of long chain PUFA fatty acids (especially C18:3n-3, C22:5 $n-3$ and C22:6 n-3) on kidney knob fat.

With those results, Horcada et al. [46] concluded that breeds, together with the production system (understood as feed system, type and duration of suckling, type of milk), are important factors that influence and modify the fatty acid profile. It is convenient to remark that in young suckling small ruminants, the fat composition is closely related to the composition of the milk consumed (especially short chain and saturated fatty acids, SFA) [38, 46]. Therefore, the possibility of using the fat composition as a tool to discriminate breeds and fattening diets of goat kids has been proposed [46, 47].

Age and slaughter weight also modify some fatty acid groups on intramuscular fat depot. In Ref. [38], it was reported that fat composition of the meat aptitude breed Bermeya slaughtered at two different weights (7 kg CCW vs. $10.5 \mathrm{~kg} \mathrm{CCW})$ was statistically different on the percentage of PUFA, $n-6, n-3$, and its ratio. Heavy animals presented lower percentage of PUFA ( $14.16 \%$ vs. $21.49 \%), n-6$ (9.03\% vs. $14.31 \%), n-3$ ( $4.46 \%$ vs. $6.54 \%)$, and PUFA/SFA (0.32\% vs. $0.58 \%$ ) with respect to those from light weights (younger animals). In the same study, a dairy breed was analyzed (Murciano-Granadina, $5.6 \mathrm{~kg} \mathrm{CCW}$ ), and presented a fatty acid profile more similar to lamb (10 kg CCW) than to Bermeya light kids. There were no differences in SFA between the type of animals, with values comprised between 46.5 and $42.3 \%$; dairy breed had a higher percentage of MUFA (40.49\%) than meat animals in both weights, similar to $n-6$ PUFA than heavy kids (10.23\% and $8.39 \%)$, and lower $n-3(1.12 \%$ vs. $4.46 \%)$ and higher $n-6 / n-3$ (7.79\% vs. $2.26 \%)$.

Comparing kid and lamb fatty acid profile, the fatty acid profile from lamb differs more from meat goats than from dairy goats [47].

In conclusion, the intramuscular fat from suckling kids has an appropriate nutritional lipid index, and a moderate consumption may contribute to an overall balanced human diet.

\subsection{Sensory analysis}

Sensory data can be obtained from a trained taste panel, which assesses the sensory profile and the intensity of the evaluated attributes or by a consumer test where acceptability scores of the hedonic perception about the evaluated meat samples are obtained.

A trained taste panel used in [34] described goat sensory profile with the following attributes: kid and milk odor and six different flavors such as kid, fat, milk, metallic, acid, and bitter. Odor or flavor intensity between studied meat purpose breeds was not different. However, there were significant differences among breeds in the texture attributes, as tenderness, juiciness, and 
fibrousness. Sensory attributes were highly correlated with each other, being the breeds considered as most tenders also those that had the highest values on juiciness and lower fibrousness values.

Also, no differences in flavor between different aptitude crossbreds have been reported in the other study [37], with a flavor intensity comprised between 6.3 and 6.1 on a 9-point scale, but there were differences in tenderness and juiciness. The most tender and juiciest breed (a crossbred from meat and wild aptitude) was the same breed that presented the lowest cooking losses and lowest shear forcé, as it was expected [37].

Differences between dairy and meat purpose kids have been reported on the intensity of species odor and flavor [38], which was slightly higher in dairy kids. Differences reported on tenderness and juiciness were affected by breed and slaughter weight. Kids from heavy meat purpose breeds had lower values on those variables than light kids, in which values were also similar to a dairy breed. There were no differences in other sensory variables such as fat odor, fibrousness, greasiness, or other flavors (metallic, fat, milk, acid, spicy).

Also, in [34], slaughter weight not only produced significant differences in kid and milk odors, but also in tenderness and juiciness. Applying a multivariate analysis, light kids presented a tenderer and juicier meat than heavy kids whose species and milk odors were more intense than in younger animals [34].

Then, slaughter weight has a stronger effect in organoleptic characteristics than breed per se, as happened in lamb, because the volatile precursors of aroma formation $[48,49]$ and their contribution to species flavor increases with animal age, although it could be modified by the diet [50].

The differences between light and heavy carcasses in fat odor intensities (higher for heavy) can be associated with differences in the amount of adipose tissue, which imports the distinctive aromas in lamb [51], because fat traps aromatic compounds and enhances taste [52].

Analyzing the effect of the breed on consumer acceptability, consumers reported differences between breeds on flavor acceptability, tenderness acceptability, and overall acceptability [16]. Kids from dairy breeds presented higher scores than other meat purpose breeds, which may be associated with the precociousness of fat deposition in these breeds and its highest fatness scores [16].

When different slaughter weights are compared [38], heavy kids present lower tenderness acceptability scores, without differences in flavor acceptability and being the overall acceptability similar between heavy and light kids of meat purpose. This indicates that in spite of several intrinsic differences between those light or heavy kids, in general, the consumer do not perceive the final product as different, despite coming from different weights, ages or production systems, with a suitable overall acceptability.

However, kids from dairy breeds had the highest values of acceptability both in tenderness and in overall respect to any other types (light or heavy), which show that dairy kids are preferred respect to those from meat breeds. 
As it has been previously commented in the introduction, consumption of goat meat in Western countries is less common than lamb consumption, but there are no doubts about the specificity and own sensorial characteristics, attributes, and qualities of goat species. As Hungarian Sheep and Goat Breeders' Association have reported [20] "Goat meat is a very palatable food with several positive physiological effects and nutritional values. Generally we found in the market meat from young animals, mainly as a by-product of milk production." Animals are slaughtered young because consumers do not favor the strong taste and odor of older animals. Also the best meat yields are those from kids of 8-10 weeks old. Goat meat can be prepared in various ways, being the most usual fried or stuffed and roasted. Goat meat is slightly sweet, so it requires careful seasoning.

Comparing plain or seasoned products from goat or beef [53] showed that goat meat is always differentiated in a triangular test. However, acceptability scores are as high as those from beef, when goat products are served before beef products. It was hypothesized that the different order effect is affected by the familiarity or unfamiliarity that the consumer or panelist has with the product taste. When goat meat was served first, panelists had no comparison basis for their rating of the unfamiliar meat, and thus goat meat was scored better than when it served after a more familiar meat as beef.

In Ref. [54], it is shown how it is possible to differentiate and create a sensory map with 15 species by their own attributes. Excluding color, which was the main differentiating factor between species, the odor and flavor explained $66 \%$ of variation with texture representing $13 \%$. Goat shows gamier, metallic and liver odor-flavor than lamb. Goat meat attributes were more related to beef and beaver meat than to lamb. In this sense, there are a few studies that compare kid and lamb meat, and results as those from $[55,56]$ reflect that lamb and goat differed mainly in aroma, tenderness, or fibrousness, but in very young animals, those differences decreases tending meat of both species to be similar. Nevertheless, [57] have not reported statistical differences in odor, juiciness or overall palatability between both species. And as reported in [16], consumers under different testing environments had some similar acceptability scores for lamb and kids.

\section{Conclusions}

In European countries, usually goats are slaughtered with a low weight being kid or suckling kid, the most demanded product, presenting carcasses that usually are lean, and having poor conformation and low subcutaneous fat.

In tissue composition, goat species present generally a high muscle and bone percentages and low fat contents. Perirenal fat is very important in goat, being also a remarkable criterion for carcass quality and classification.

Related to meat quality attributes, $\mathrm{pH}$ results usually are higher in goat with respect to lambs. Also, goat (kids) presented low color intensity (small values of luminosity, yellowness, Chroma and hue). 
Usually tenderness is higher in lamb than in goats; The difference associated with differences in collagen content and other factors such as fat content or muscle fiber composition also affects tenderness. Small differences between breeds are reported only at short aging periods.

Related to proximate composition, meat from goat is characterized by a higher water content, lower energetic contribution, and lower fat content than ovine species. Being, on kids, possible discriminate breeds (purpose) and fattening diets by their fat composition.

Related to sensorial acceptability of meat from goat, there are differences between breeds and age of slaughter, being preferred young kids respect heavy or adults by presenting not so strong taste. Overall, milky to meat purpose kids mainly affected by a higher tenderness of milky kids are also preferred.

It is undeniable that goat meat has it own characteristics, which are different from other ruminant species; however, it presents a good acceptability comparable with lamb meat, a species whose consumption is more worldwide spread, especially when young and milk kids are considered; then, an adequate cultural development of goat meat characteristics could contribute to its consolidation by increasing its demand, because it has its own characteristics and singular high-quality attributes.

\section{Acknowledgements}

The authors thank the Goat Breeders' Associations that collaborate on the diverse projects developed and also authors thank the Animal Production personnel which contributes on the cited studies.

\section{Author details}

Ana Guerrero*, María del Mar Campo, José Luis Olleta and Carlos Sañudo

*Address all correspondence to: guerrerobarrado@gmail.com

Department of Animal Production and Food Science, Instituto Agroalimentario de Aragón (IA2), Universidad de Zaragoza-CITA, Zaragoza, Spain

\section{References}

[1] Shrestha JNB, Fahmy MH. Breeding goats for meat production: A review. 1. Genetics resources, management and breed evaluation. Small Ruminant Research. 2005;58:93-106. DOI: 10.1016/S0921-4488(03)00183-4

[2] FAO-Faoestat. Food and Agriculture Organization of the United Nations. 2017. Available from: http://www.fao.org/faostat/en/\#data. [Accessed: October 09, 2017] 
[3] Capote J. Environments and goats around the world: importance of genetic and management factors. In: Kukovics S, editor. Sustainable Goat Breeding and Goat Farming in Central and Eastern European Countries-European Regional Conference on Goats. Rome, Italy: Food and Agriculture Organization of the United Nations; 2016. pp. 1-6

[4] Kukovic S. Summary of the conference and the fao workshop. In: Kukovics S, editor. Sustainable Goat Breeding and Goat Farming in Central and Eastern European Countries European Regional Conference on Goats. Rome: Food and agriculture Organization of the United Nations; 2016

[5] Council Regulation(EEC) No2137/92 of 23July 1992 concerning the Community scale for the classification of carcases of ovine animals and determining the Community standard quality of fresh or chilled sheep carcases and extending Regulation (EEC) No 338/91. Available from: http://eur-lex.europa.eu/legal-content/ES/TXT/?uri=CELEX\%3A31992R2137. [Accessed: October 20, 2017]

[6] Commission Regulation (EEC) No 461/93 of 26 February 1993 laying down detailed rules for the Community scale for the classification of carcases of ovine animals. Available from: http://eur-lex.europa.eu/legal-content/ES/TXT/?uri=CELEX\%3A31993R0461. [Accessed October 20, 2017]

[7] Fisher AV, de Boer H. The EAAP standard method of sheep carcass assessment. Carcass measurements and dissection procedures. Report of the EAAP working group on carcass evaluation, in cooperation with the CIHEAM Instituto Mediterraneo of Zaragoza and the CEC Directorate General for Agriculture in Brussels. Livestock Production Science. 1994;38:149-159. DOI: 10.1016/0301-6226(94)90166-X

[8] Colomer-Rocher F, Morand-Fehr P, Kirton AH, Delfa R, Sierra I. Métodos normalizados para el estudio de los caracteres cuantitativos y cualitativos de las canales caprinas y ovinas. Cuadernos INIA. 1988;17. 41 pp

[9] Ruiz de Huidobro F, Miguel E, Cañeque V, Velasco S. Conformación, engrasamiento y sistemas de clasificación de la canal ovina. In: Cañeque V, Sañudo C, editors. Estandarización de las metodologías para evaluar la calidad del producto (animal vivo, canal, carne y grasa) en los rumiantes. Monografías INIA, Serie Ganadera N ${ }^{\circ}$. Madrid, Spain: INIA; 2005. pp. 143-169

[10] Delfa R, Teixeira A, Colomer-Rocher F. Composición regional y tisular de la canal caprina. In: Cañeque V, Sañudo C, editors. Estandarización de las metodologías para evaluar la calidad del producto (animal vivo, canal, carne y grasa) en los rumiantes. Monografías INIA, Serie Ganadera Nº 3. Madrid, Spain: INIA; 2005. pp. 189-198

[11] Honikel KO. Reference methods for the assessment of physical characteristics of meat. Meat Science. 1998;49:447-457. DOI: 10.1016/S0309-1740(98)00034-5

[12] Lepetit J, Culioli J. Mechanical properties of meat. Meat Science. 1994;36:203-237. DOI: 10.1016/0309-1740(94)90042-6 
[13] Campo MM, Santolaria P, Sañudo C, Lepetit J, Olleta JL, Panea B, Albertí P. Assessment of breed type and ageing time effects on beef meat quality using two different texture devices. Meat Science. 2000;55:371-378. DOI: 10.1016/S0309-1740(99)00162-X

[14] Bligh EG, Dyer WJ. A rapid method of total lipid extraction and purification. Canadian of Biochemistry and Physiology. 1959;37:911-917

[15] Sañudo C, Nute GR, Campo MM, María G, Baker A, Sierra I, Enser ME, Wood JD. Assessment of commercial lamb meat quality by British and Spanish taste panels. Meat Science. 1998;48:91-100. DOI: 10.1016/S0309-1740(97)00080-6

[16] Guerrero A, Campo MM, Cilla I, Olleta JL, Alcalde MJ, Horcada A, Sañudo C. A comparison of laboratory-based and home-based test of consumer preferences using kid and lamb meat. Journal of Sensory Studies. 2014;29:201-210. DOI: 10.1111/joss.12095

[17] Cañeque V, Sañudo C, editors. Estandarización de las metodologías para evaluar la calidad del producto (animal vivo, canal, carne y grasa) en los rumiantes. Monografías INIA, Serie Ganadera Nº 3. Madrid, Spain: INIA; 2005

[18] Boccard R, Butchter L, Casteels E, Cosentino E, Dransfield E, Hood DE, Joseph RL, Macdougall DB, Rhodes DN, Schön I, Tinbergen BJ, Touraille C. Procedures for measuring meat quality characteristics in beef production experiments. Report of a working group in the commissions of the European communities (CEC) beef production research programme. Livestock Production Science. 1981;8:385-397. DOI: 10.1016/ 0301-6226(81)90061-0

[19] ASPA. Metodiche per la determinazione delle caratteristiche qualitative della carne. Perugia, Italy: Università degli Studi di Perugia, Centro Stampa Univarsitá; 1996. 101 pp

[20] Seregi J, Kovács A. Data on the importance of goat milk and meat in human nutrition. In: Kukovics S, editor. Sustainable Goat Breeding and Goat Farming in Central and Eastern European Countries-European Regional Conference on Goats. Rome, Italy: Food and Agriculture Organization of the United Nations; 2016. pp. 195-202

[21] Guerrero A, Campo MM, Olleta JL, Sañudo C. Challenges to meat consumption worldwide. Book of abstract of 54th annual meeting of Brazilian Society of Animal Production (SBZ); 24-29 July 2017; Foz do Iguaçu, Brazil

[22] Guerrero A, Valero MV, Campo MM, Sañudo C. Some factors that affect ruminant meat quality: From the farm to the fork. Review. Acta Scientarium. Animal Science. 2013;35:335-347. DOI: 10.4025/actascianimsci.v35i4.21756

[23] Colomer-Rocher F, Morand-Fehr P, Kirton AH, Delfa R, Sierra I. Métodos normalizados para el estudio de los caracteres cuantitativos y cualitativos de las canales caprinas y ovinas. Vol. 17. Madrid: Cuadernos INIA; 1988. 41 pp

[24] Sañudo C, Campo MM, Muela E, Olleta JL, Delfa R, Jimenez-Badillo R, Alcalde MJ, Horcada A, Oliveira I, Cilla I. Carcass characteristics and instrumental meat quality 
of suckling kids and lambs. Spanish Journal of Agricultural Research. 2012;10:690-700. DOI: 10.5424/sjar/2012103-670-11

[25] Delfa R, Teixeira A, Colomer-Rocher F. Conformación, engrasamiento y sistemas de clasificación de la canal caprina. In: Cañeque V, Sañudo C, editors. Estandarización de las metodologías para evaluar la calidad del producto (animal vivo, canal, carne y grasa) en los rumiantes. Monografías INIA, Serie Ganadera N 3. Madrid, Spain: INIA; 2005. pp. $181-188$

[26] Colomer-Rocher F, Morand-Fehr P, Kirton AH. Estándar methods and procedures for goat carcass evaluation, jointing and tissue separation. Livestock Production Science. 1987;17:149-159. DOI: 10.1016/0301-6226(87)90060-1

[27] Jiménez-Badillo MR. Caracterización de la calidad de la canal y carne del cabrito Transomontano (DPO) [Thesis]. Spain: Universidad de Zaragoza; 2007

[28] Gallo C, Le Breton Y, Wainnright I, Berkhoff M. Body and carcass composition of male and female Criollo goats in the south of Chile. Small Ruminant Research. 1996;23:163-169. DOI: 10.1016/S0921-4488(96)00940-6

[29] Todaro M, Corrao A, Barone CMA, Schinelli R, Occidente M, Giaccone P. The influence of age and slaughter and litter size on some quality traits of kid meat. Small Ruminant Research. 2002;44:75-80. DOI: 10.1016/S0921-4488(02)00035-4

[30] Cardoso AM. Composiçao da carcaça de cabritos da raça serrana ecotipo jarmelista. Métodos para estimar a composição da carcaça [Thesis]. Portugal: Universidade de Trás0os-Montes e Alto Douro; 2010

[31] Jiménez-Badillo MR, Rodrigues S, Sanudo C, Teixeira A. Non-genetic factors affecting live weight and daily weight in Serrana Transmontano kids. Small Ruminant Research. 2009;84:125-128. DOI: 10.1016/j.smallrumres.2009.06.002

[32] Hammond J. Growth and Development of Hutton Qualities in Sheep. Edinburgh: Oliver and Boyd; 1932

[33] Panea B, Ripoll G, Sañudo C, Horcada A, Alcalde MJ. Influencia del sistema de lactancia sobre la calidad de la carne de cabrito de las razas Murciano Granadino y Malagueña. Tierras de Castilla y León: Ganadería. 2009;158:37-39

[34] Ripoll G, Alcalde MJ, Horcada A, Campo MM, Sañudo C, Teixeira A, Panea B. Effect of slaughter weight and breed on instrumental and sensory meat quality of suckling kids. Meat Science. 2012;92:62-70. DOI: 10.1016/j.meatsci.2012.04.011

[35] Madruga MS, Arruda SGB, Nascimento JA. Castration and slaughter age effects on nutritive value of "mestiço" goat meat. Meat Science. 1999;52:119-125. DOI: 10.1016/ S0309-1740(98)00156-9

[36] Font-i-Furnols M, Guerrero L. Consumer preference, behavior and perception about meat and meat products: An overview. Meat Science. 2014;98:361-371. DOI: 10.1016/j. meatsci.2014.06.025 
[37] Dhanda JS, Taylor DG, Murray PJ. Part 1. Growth, carcass and meat quality parameters of male goats: Effects of genotype and liveweight at slaughter. Small Ruminant Research. 2003;50:57-66. DOI: 10.1016/S0921-4488(03)00112-3

[38] Guerrero A, Lemes JS, Campo MM, Olleta JL, Muela E, Resconi VC, Guerra VM, AssisMacedo F, Sañudo C. Características de la canal y de la carne en la raza caprina Bermeya. Comparación con el Ternasco de Aragón y lechales de la raza Murciano-Granadina. Itea. 2016;112:271-285. DOI: 10.12706/itea.2016.017

[39] Lawrie RA. Meat Science. Oxford: Pergamon Press; 1985

[40] Santos VAC, Silva SR, Azevedo JMT. Carcass composition and meat quality of equally mature kids and lambs. Journal of Animal Science. 2008;86:1943-1950. DOI: 10.2527/ jas.2007-0780

[41] Dransfield E. Optimisation of tenderisation, ageing and tenderness. Meat Science. 1994;36:105-121. DOI: 10.1016/0309-1740(94)90037-X

[42] Devine CE, Graafhuis AE. The basal toughness of unaged lamb. Meat Science. 1995; 39:285-291. DOI: 10.1016/0309-1740(94)P1829-K

[43] USDA. Nutrient Database for Standard Reference, Release 27. Nutrient Data Laboratory Home Page. 2017. Available from: http://ndb.nal.usda.gov/ndb/ [Accessed: October 10, 2017]

[44] BEDCA. Spanish Food Composition Database. Available from: http://www.bedca.net/ bdpub/. [Accessed: October 10, 2017]

[45] Marichal A, Castro N, Capote J, Zamorano N, Arguello A. Effects of live weight at slaughter $(6,10$ and $25 \mathrm{~kg})$ on kid carcass and meat quality. Livestock Production Science. 2003;83:247-256. DOI: 10.1016/S0301-6226(03)00113-1

[46] Horcada A, Ripoll G, Alcalde MJ, Sañudo C, Teixeira A, Panea B. Fatty acid profile of three adipose depots in seven Spanish breeds of suckling kids. Meat Science. 2012;92:89-96. DOI: 10.1016/j.meatsci.2012.04.018

[47] Horcada A, Campo MM, Polvillo O, Alcalde MJ, Cilla I, Sañudo C. A comparative study of fatty acid profiles of fat in commercial Spanish suckling kids and lambs. Spanish Journal of Agricultural Research. 2014;12:427-435. DOI: 10.5424/sjar/2014122-4566

[48] Madruga MS, Elmore JS, Dodson AT, Mottram DS. Volatile flavor profile of goat meat extracted by three widely used techniques. Food Chemistry. 2009;115:1081-1087. DOI: 10.1016/j.foodchem.2008.12.065

[49] Madruga MS, Elmore JS, Oruna-Concha MJ, Balagiannis D, Mottram DS. 2010. Determination of some water-soluble aroma precursors in goat meat and their enrolment on flavour profile of goat meat. Food Chemistry. 2010;123:513-520. DOI: 10.1016/j.foodchem. 2010.04.004 
[50] Watkins PJ, Kearney G, Rose G, Allen D, Ball AJ, Pethick DW, Warner RD. Effect of branched-chain fatty acids, 3-methylindole and 4-methylphenol on consumer sensory scores of grilled lamb meat. Meat Science. 2014;96:1088-1094. DOI: 10.1016/j.meatsci. 2012.08.011

[51] Jeremiah LE, Tong AKW, Gibson LL. The infuence of lamb chronological age, slaughter weight, and gender. Flavor and texture profiles. Food Research International. 1998;31:227-242. DOI: 10.1016/S0963-9969(98)00084-2

[52] Enser M. Meat lipids. In: Hamilton RJ, editor. Developments in Oils and Fats. London: Blackie Academia and Professional; 1995. pp. 1-31

[53] Rhee KS, Myers CE, Waldron DF. Consumer sensory evaluation of plain and seasoned goat meat and beef products. Meat Science. 2003;65:785-789. DOI: 10.1016/S03091740(02)00283-8

[54] Rodbotten M, Kubberod E, Lea P, Ueland O. A sensory map of the meat universe. Sensory profile of meat from 15 species. Meat Science. 2004;68:137-144. DOI: 10.1016/j. meatsci.2004.02.016

[55] Smith GC, Pike MI, Carpenter ZL. Comparison of the palatability of goat meat and meat from four other animal species. Journal of Food Science. 1974;39:1145-1146

[56] Schönfeldt HC, Naudé RT, Bok W, Van Heerden SM, Smit R. Flavor and tenderness related quality characteristics of goat and sheep meat. Meat Science. 1993;34:363-379. DOI: 10.1016/0309-1740(93)90084-U

[57] Sen AR, Santra A, Karim SA. Carcass yield, composition and meat quality attributes of sheep and goat under semiarid conditions. Meat Science. 2004;66:757-763. DOI: 10.1016/ S0309-1740(03)00035-4 